held at Rothamsted (see Nature, 161, 364; 1948). The report of this Conference is in the press at Chronica Botanica Co., Waltham, Mass. The second symposium of this series was held during June 14-19, 1948, at Utrecht; it dealt with the theoretical basis of botanical nomenclature and systematics. The full report will also be published by the Chronica Botanica Co. A third symposium was the first International Congress on the Physio-Pathology of Animal Reproduction at Milan; it lasted two days (June 21-22, 1948) and its theme was: "Interactions between Eggs and Sperm". The full report is to be published by its secretary, Prof. T. Bonadonna, Via Fratelli Bronzetti 17, Milan. A symposium on Terminology of Cytogenetics and Genetics was held at Stockholm during July 15-16, 1948. This symposium carriod further the work done at the pre-war symposium held in London during August 14-15, 1939. A committee has been formed to supervise the preparation of the full report, which probably will be published as a separate number of Bibliographia Genetica. Finally, a fifth symposium was held at Stockholm during August 5-7, 1948, which discussed the scientific foundations of an international organ. isation for combating agricultural pests. A pro. gramme for further work on the subject has been drawn up; and the report of the meeting will be published by the general secretary of the International Union, Prof. P. Vayssière, Muséum d'Histoire Naturelle, Paris.

\section{City and Guilds of London Institute}

THE report of the Council of the City and Guilds of London Institute for 1947 gives ample evidence of the Institute's growing activities. There has been a large increase in the number of students at the City and Guilds College, particularly postgraduate and research students. In the Department of Technology the total number of candidates examined was 47,807, 7,336 higher than the previous highest total of 40,471 recorded in 1939. Among the regulations and syllabuses for existing examinations which have been revised during 1947 are those of petroleum and petroleum products, electrical ongineering practice, road service work and motor-vehicle electrician's work; while among syllabuses at present being considered for introduction later into the examinations conducted by the technology department are courses in works administration subjects for craftsmen, servicing and maintenance for instrument mechanics, and courses for electrical apprentices in iron and steel and other heavy engineering work. Copies of the report may be obtained from Gresham College, Basinghall Street, London, E.C.2.

\section{Exhibition of Radiographs}

AN exhibition of industrial radiographs will be held at the spring meeting of the Industrial Radiology Group at the Institute of Physics on February 18 and 19, 1949. Entries should be suitable for showing on standard viewing lanterns (mounted prints may also be submitted) and should, wherever possible, be accompanied by photographs or samples of the specimens which they represent. A short description should accompany each entry. Intending exhibitors should apply to the Institute of Physics, 47 Belgrave Square, London, S.W.1, for entry forms.

\section{"Animals of Australia"}

THE third of the series of natural history booklets has now been published by the Glasgow Art Galleries and Museum. Like the first two of the series, "Animals of Africa" and "Animals of India", the new booklet has been written primarily as an account of the Australian habitat group, one of the large groups in the Mammal Court of the Museum. The booklet contains a simple description of the life and habits of each of the animals as well as a photograph and outline drawing which serves as a key to the display.

\section{Announcements}

THE president of the Royal Society has appointed the following vice-presidents for the ensuing year : Sir Thomas Merton, treasurer of the Royal Society ; Sir Edward Salisbury, biological secretary of the Royal Society, director of the Royal Botanic Gardens, Kew ; Sir James Chadwick, master of Gonville and Caius College, Cambridge; Prof. A. C. Hardy, Linacre professor of zoology in the University of Oxford.

Dr. H. GReinacher, professor of experimental physics in the Faculty of Sciences of the University of Berne, has been awarded the Theodor Kocher Prize by the University in recognition of his skill in experimental work, specially for the development of the 'Greinacher circuit', widely used in applied X-rays. This circuit, which was described in 1914 (Deutsch. Phys. Gesell. Verh., 16, 320; April 15, 1914), is one of the best-known circuits that combine voltage-multiplying with a constant potential.

Dr. F. A. Burchardt, of Magdalen College, has been appointed director of the Oxford University Institute of Statistics, with effect from January 1, in succession to Mr. D. G. Champernowne, now professor of statistics in the University.

Mr. A. W. Hendry has been appointed to the University readership in civil engineering tenable at King's College, University of London, as from May 1, 1949. The title of professor of chemical pathology in the University has been conferred on Dr. Jocelyn Patterson, in respect of the post held by him at Charing Cross Hospital Medical School. The degree of D.Sc. has been conferred on Mr. E. R. Leonard, an internal student.

The Langley Memorial Prize, offered by the London School of Hygiene and Tropical Medicine, and open to competition among officers, past and present, of the West African medical departments, has been awarded to Dr. D. Fitzgerald Moore for an essay entitled "Nutritional Eye Disease and Effects of Nutritional Retrobulbar Neuritis".

Trintry College, Cambridge, offers research studentships and Dominion and Colonial exhibitions every year ; the next elections will take place in July 1949. Research studentships are open to graduates of universities other than Cambridge who are not more than twenty-six years of age, although in computing his age a candidate may deduct any period of war service. The exhibitions are open to undergraduates as well as those wishing to undertake research. Applications, to be sent through the head of the candidate's university, must reach the Senior Tutor, Trinity College, Cambridge, not later than May 1, 1949.

Two Christmas Lectures, for older children, will be delivered at the Institution of Electrical Engineers by Dr. P. Dunsheath, under the general title "Electricity : a Giant Harnessed". The Lectures will be given on December 29 and 30 at 3 p.m. 